\title{
Transductional Analysis of Cysteine Mutants in Proteus mirabilis
}

\author{
BY W. O. K. GRABOW* \\ Department of Microbiology, University of Pretoria, Pretoria, South Africa
}

(Accepted for publication 30 September I971)

\begin{abstract}
SUMMARY
Seventy-three cysteine (cys) auxtrophs of Proteus mirabilis strain I 3 were arranged in six transductional groups. Members of these groups had nutritional requirements similar to Salmonella typhimurium and Escherichia coli cys mutants. The chromosomal topography of the $P$. mirabilis mutants resembles that of $S$. typhimurium and $E$. coli cys mutants in that they are not arranged in an operon and cys $B$ mutants are co-transducible with tryptophan markers. The $P$. mirabilis cys $G$ auxotrophs may be equivalent to $S$. typhimurium cys $I$ and $J$ mutants which have similar nutritional requirements. In $P$. mirabilis cysG is closely linked to cysC and the $S$. typhimurium cys $C, D, H, I, J$ cluster may also be present in this organism. The $P$. mirabilis cys $E$ mutants, which are co-transducible with an arginine gene cluster, seem to lack $O$ acetylserine sulphhydrylase activity.
\end{abstract}

\section{INTRODUCTION}

Nine cysteine (cys) genes have been mapped in Salmonella typhimurium (Fig. 2). With the exception of $c y s B$, which may have a regulatory function (Spencer, Collins \& Monty, 1967), the genes code for enzymes (Mizobuchi, Demerec \& Gillespie, 1962; Dreyfuss \& Monty, 1963; Siegel, Click \& Monty, 1964; Kredich \& Tomkins, 1966; Henderson \& Loughlin, I968). Apparently homologous $S$. typhimurium genes map at similar locations in Escherichia coli (Taylor, 1970). The cysB-trp linkage group represents the only known inversion of the chromosome in these organisms (Sanderson, 1970). Five transduction groups of Pseudomonas aeruginosa cys mutants are not linked (Calhoun \& Feary, 1969) and two cysteine markers of Bacillus subtilis are also located far apart (Dubnau, Goldthwaite, Smith \& Marmur, 1967). Streptomyces coelicolor resembles $S$. typhimurium in that its cysC and $D$ genes are closely linked (Hopwood, 1967).

In Proteus mirabilis strain I3 (Coetzee \& Sacks, 1960a) the cysteine pathway (Grabow \& Smit, 1967) is similar to that in Salmonella typhimurium (Fig. 1), but the chromosomal topography of corresponding mutants has not been investigated. The cys $E$ gene of $P$. mirabilis is co-transducible with the $\arg E, C, B, G, H$ cluster (Böhme, 1964; Prozesky \& Coetzee, 1966; Prozesky, 1968). These genes are also linked in Proteus vulgaris but not in Providence (Coetzee \& Prozesky, I969).

This communication deals with transductional analysis of six phenotypic groups of Proteus mirabilis cys auxotrophs. The results are necessary for studies of the regulation of the cysteine pathway (Spencer et al. 1967) and they are of taxonomic importance (Coetzee, Smit \& Prozesky, 1966; Coetzee \& Prozesky, 1969; Krizsanovich, de Klerk \& Smit, I969; Jones \& Sneath, 1970).

* Present address: National Institute for Water Research of the South African Council for Scientific and Industrial Research, P.O. Box 395, Pretoria, Republic of South Africa. 


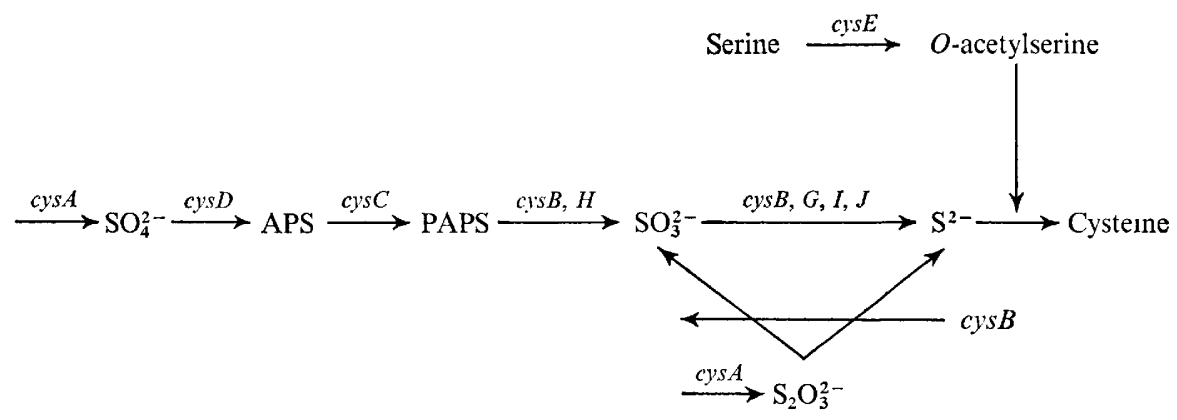

Fig. I. Pathway of cysteine synthesis in Salmonella typhimurium (Dreyfuss \& Monty, 1963; Kredich et al. 1969). APS $=$ adenosine $5^{\prime}$-phosphosulphate; PAPS $=3^{\prime}$-phosphoadenosine $5^{\prime}$-phosphosulphate $; \mathrm{SO}_{4}{ }^{2-}=$ sulphate $; \mathrm{SO}_{3}{ }^{2-}$ sulphite $; \mathrm{S}_{2} \mathrm{O}_{3}{ }^{2-}=$ thiosulphate $; \mathrm{S}^{2-}=$ sulphide $;$ cys $A=$ sulphatethiosulphate permease; $\operatorname{cys} B=$ gene concerned with adenylyl sulphate-3'-phosphate reductase, sulphite reductase and thiosulphate reductase; $c y s C=$ APS kinase; $c y s D=A T P$ sulphurylase; $c y s E=$ serine transacetylase activity of the cysteine synthetase enzyme; cys $G, I, J=$ genes concerned with sulphite reductase; $c y s H=$ adenylyl sulphate- $3^{\prime}$-phosphate reductase.

\section{METHODS}

Media and chemicals. The minimal medium (MM) agar has been described (Grabow \& Smit, 1967) and the broth was that of Coetzee \& Sacks (I960b). $O$-Acetyl-DL-serine was obtained from Dr Theodor Schuchardt, München, Germany; vitamin $\mathbf{B}_{12}$ from British Drug Houses, Poole, Dorset; $S$-methyl-L-cysteine from Calbiochem, California, U.S.A.; DL-cystathionine from Sigma Chemical Company, St Louis, U.S.A.; and all other amino acid growth factors from Nutritional Biochemical Corporation, Cleveland, Ohio, U.S.A. Inorganic sources of sulphur were analytical grade products (Postgate, I963) from E. Merck Darmstadt, Germany. $O$-Succinyl-DL-homoserine was prepared according to the method of Flavin \& Slaughter (1965).

Bacteria. Cysteine auxotrophs were obtained by exposing Proteus mirabilis strain 13 to ultraviolet light or manganese chloride+hydrogen peroxide (Grabow \& Smit, 1967). Nutritional requirements were determined auxanographically (Grabow \& Smit, 1967) and by streaking on MM agar containing growth factors (Mizobuchi et al. 1962). For the latter test MM agar was supplemented with sulphur-containing substances at concentrations of $2 \times 10^{-2} \mathrm{M}$ (molar with respect to sulphur). Additional tests were done with thiosulphate at a concentration of $2 \times 10^{-4} \mathrm{M}$ (Mizobuchi et al. 1962). Glycine, serine and homoserine were incorporated at $50 \mu \mathrm{g} / \mathrm{ml}$ and vitamin $B_{12}$ at $0.1 \mu \mathrm{g} / \mathrm{ml}$ (Grabow, 1972). Results were recorded after $48 \mathrm{~h}$ incubation. Growth was regarded as positive when it was comparable to that of the mutant on cysteine-supplemented MM agar. Double mutants were isolated by the methods of Prozesky \& Coetzee (1966) and Prozesky (1967). Arginine mutants were kindly supplied by Professor O. W. Prozesky and tryptophan markers were isolated and characterized by the above methods. Strains were maintained on agar slopes at $4^{\circ}$. Subcultures were made regularly to prevent the selection of double mutants (Gillespie, Demerec \& Itikawa, 1968). Incubation was at $37^{\circ}$.

Transduction. The general phage techniques were those of Adams (1959). Lysates of the transducing phage $34 \cdot{ }^{1} 3$ (Coetzee \& Sacks, I960a) with plaque-forming titres of $5 \times 10^{9}$ to $2 \times 10^{10} / \mathrm{ml}$ were prepared by an agar layer technique (Prozesky, de Klerk \& Coetzee, 1965). Final lysates contained less than 50 plaque-forming units of phage I 3 vir per ml (Prozesky, 1968; Coetzee \& Smit, 1970). The transduction procedure has been described 
(Prozesky \& Coetzee, 1966; Prozesky, 1968). Controls for absence of viable bacteria in phage lysates as well as controls in which recipients were treated with lysates prepared on homologous and wild-type bacteria respectively were included. Wild-type transductants were selected on MM agar and donor-type transductants on MM agar supplemented with appropriate growth factors. Plates were scored after $48 \mathrm{~h}$ and those with donor-type transductants replicated to MM agar for detection (Lederberg \& Lederberg, I952). Purity of transductant clones was tested according to Prozesky (1968).

Genetic mapping. Co-transduction of genes was tested by two-point crosses, donorphenotype transductions and transduction of double mutants with wild-type donors (Demerec et al. 1956; Clowes, 1958b; Mizobuchi et al. 1962; Prozesky \& Coetzee, 1966; Prozesky, 1968).

\section{RESULTS}

Auxotrophic mutants. Seventy-three non-leaky cysteine mutants of Proteus mirabilis strain 13 with low reversion frequencies were divided into six phenotypic groups by their growth responses to precursors of cysteine (Table $\mathrm{I}$ ).

The nutritional requirements of the cys $A, B, C, K$ and $G$ groups resemble those of cys $A$, $B, C, E$ and $G$ mutants of Salmonella typhimurium (Clowes, I958a; Mizobuchi, et al. 1962). Mutants with nutritional requirements similar to those of the Proteus mirabilis cysE auxotrophs have not been described in S. typhimurium or Escherichia coli. None of the auxotrophs responded to dithionate, sulphur, lanthionine, cysteic acid, glycine, serine, homoserine, $O$-succinylhomoserine or vitamin $B_{12}$. Growth response to cysteine sulphinic acid was not tested since it serves as a source of sulphite (Leinweber \& Monty, I96I) and yields results similar to metabisulphite and sulphite in S. typhimurium (Mizobuchi et al. 1962). Differences between $P$. mirabilis mutants and the analogous $S$. typhimurium auxotrophs are that the $P$. mirabilis strains do not respond to lanthionine (Demerec et al. 1956; Clowes, 1958a) and that cys $A$ mutants do not grow with thiosulphate (Mizobuchi $e$ t al. 1962). The $P$. mirabilis cys $A, C, E$ and $G$ mutants grow equally well on cysteine or methionine whereas homologous $E$. coli (Lampen, Jones \& Perkins, 1947; Simmonds, 1948) and S. typhimurium (Demerec et al. 1956; Clowes, 1958a) auxotrophs grow poorly on methionine. In the latter respect the $P$. mirabilis mutants resemble similar auxotrophs of Neurospora (Horowitz, 1947) and Pseudomonas aeruginosa (Calhoun \& Feary, 1969). The inability of cys $B$ and $K$

Table I. Nutritional requirements of Proteus mirabilis cysteine auxotrophs

Growth factor
Sulphate
Dithionite
Metabisulphite
Sulphite
Thiosulphate
Sulphide
Cysteine
S-Methylcysteine
O-Acetylserine
Cystathionine
Homocysteine
Methionine
Number of mutants
in each group

\begin{tabular}{cccccc}
\multicolumn{7}{c}{ Growth response of mutants } \\
$\overbrace{c y s A}$ & $c y s C$ & $c y s G$ & $c y s B$ & $c y s K$ & $c y s E$ \\
- & - & - & - & - & - \\
+ & + & + & - & - & - \\
+ & + & - & - & - & - \\
+ & + & - & - & - & - \\
- & + & + & - & - & - \\
+ & + & + & + & - & - \\
+ & + & + & + & + & + \\
+ & + & + & - & - & + \\
- & - & + & - & + & - \\
+ & + & + & - & - & + \\
+ & + & + & - & - & + \\
+ & + & + & 3 & 8 & + \\
9 & 5 & 30 & & &
\end{tabular}


mutants to grow with $S$-methylcysteine, cystanthionine, homocysteine or methionine cannot be explained. The $P$. mirabilis cys $B$ mutants seem to resemble members of the $S$. typhimurium $c y s B b$ complementation group which do not respond to thiosulphate or dithionite (Mizobuchi et al. 1962). Cultures of cysteine mutants were kept on agar slopes at $4^{\circ}$ for more than a year and double mutants (Gillespie et al. 1968) did not appear.

All the mutants used behaved like point mutations. No true deletions (Hartman, Loper \& Šerman, 1960) or mixed transductant clones (Prozesky, I968) were encountered. Ditto deletions of cys genes like those in Salmonella typhimurium (Itikawa \& Demerec, 1967) were not detected. Proteus mirabilis seems to resemble Escherichia coli in this respect (Jones-Mortimer, I968).

Table 2. Two-point transductions of cys mutants

\begin{tabular}{|c|c|c|c|c|c|c|}
\hline \multirow[b]{2}{*}{ Recipient } & \multicolumn{6}{|c|}{ Donor } \\
\hline & $\operatorname{cys} A \mathrm{I}$ & $\operatorname{cys} A 2$ & cysBI4 & cysBzo & $\operatorname{cys} C x$ & ${ } y_{s} C_{3}$ \\
\hline cys $A I$ & 0 & 5 & 1066 & I I 83 & 1202 & 1136 \\
\hline cysA2 & 3 & 0 & I 26 & $\mathrm{I} 28 \mathrm{I}$ & 1242 & 1202 \\
\hline cysA354 & 2 & 4 & I 253 & I I 86 & I 293 & I 293 \\
\hline cysBI4 & I I 38 & I I 47 & 0 & 2 & I 125 & I 193 \\
\hline cysBI7 & I 242 & I I 83 & I & 2 & 1021 & 987 \\
\hline cysB $B 20$ & 1123 & I 202 & 2 & 0 & 1034 & 1086 \\
\hline cys $C I$ & 939 & 901 & 862 & 894 & 0 & 0 \\
\hline cys $C_{3}$ & 967 & 875 & 897 & 893 & I & 0 \\
\hline cysC666 & 983 & 976 & 945 & 947 & 2 & I \\
\hline cysE6 & 1136 & I 286 & 1223 & II 23 & I 208 & 1242 \\
\hline cysE24 & 1220 & I 291 & $123 I$ & I 109 & 1070 & 989 \\
\hline cys $E 448$ & 1219 & I 287 & 1262 & 1207 & II39 & 1252 \\
\hline cysG2 & 795 & 838 & 828 & 818 & 464 & 538 \\
\hline cysG2o & $789^{\circ}$ & 894 & 786 & 874 & 421 & 636 \\
\hline cysGI795 & 939 & 875 & 847 & 963 & 434 & 674 \\
\hline cysKI3 & 880 & 921 & 821 & 818 & 763 & 649 \\
\hline cysK22 & 842 & $90 I$ & 827 & 874 & 765 & 794 \\
\hline cys $K_{32}$ & 837 & 985 & 898 & 939 & 871 & $86 I$ \\
\hline $\arg E I$ & 364 & $40 I$ & 276 & $33 I$ & 287 & 322 \\
\hline \multirow[t]{2}{*}{$\operatorname{trp}-I$} & 2289 & 2386 & 2124 & 2112 & 2217 & 2340 \\
\hline & cysE6 & cysE24 & cysGz & cysG2o & cysKr 3 & 13 \\
\hline $\operatorname{cys} A I$ & 1083 & I I 45 & I I 24 & 1030 & I 268 & I I 27 \\
\hline cys $A 2$ & I 249 & 1206 & 1287 & 1206 & 1010 & I 208 \\
\hline cysA354 & 1307 & I 286 & II 76 & I 147 & 1374 & 1284 \\
\hline cysBI4 & I I 34 & 1089 & 1090 & 1186 & I 248 & 1186 \\
\hline cysBI7 & I I 43 & I I 24 & $98 \mathrm{I}$ & 975 & 2020 & 1080 \\
\hline cysBzo & I 243 & I 206 & I034 & 1081 & 2031 & 1123 \\
\hline $\operatorname{cys} C \mathrm{I}$ & 949 & 913 & 565 & 636 & 989 & $92 \mathrm{I}$ \\
\hline cys $C_{3}$ & 868 & 973 & 574 & 706 & 1038 & 946 \\
\hline cysC666 & 1083 & 969 & 650 & 638 & 1092 & 1021 \\
\hline cysE6 & 0 & I & 1286 & 1202 & 1108 & 1212 \\
\hline cysE24 & 3 & 0 & I I 35 & I I 43 & IO2I & I099 \\
\hline cysE 448 & 4 & 3 & I I 80 & 1247 & I 295 & 1235 \\
\hline cysG2 & 891 & 842 & 0 & I & 868 & 870 \\
\hline cysGro & 935 & 946 & 0 & I & 825 & 913 \\
\hline cysGI795 & 986 & 974 & 3 & 2 & $88 I$ & 942 \\
\hline cysKI3 & 798 & 869 & 873 & 626 & 0 & 808 \\
\hline cysK22 & 846 & 823 & 842 & 813 & 4 & 842 \\
\hline $\operatorname{cys}_{32}$ & 891 & 934 & 808 & 747 & 6 & 873 \\
\hline $\arg E I$ & 286 & 231 & 342 & 312 & 325 & 308 \\
\hline trp-I & 228 I & 2310 & 2396 & 2286 & 2321 & 2342 \\
\hline
\end{tabular}

Selection was for wild-type. Colony numbers on control plates were subtracted. 
Linked transduction of cysteine genes. Reciprocal two-factor crosses yielded relatively low transduction frequencies between $c y s C$ and $G$ and between $c y s E$ and $\arg E$ mutants which indicates that these pairs are cotransducible (Table 2).

Small numbers of transductants were obtained from crosses between mutants which belonged to the same phenotypic group which indicated that the six phenotypic groups (Table I) may be equivalent to different genes (Demerec et al. I956). It does not exclude the possibility that some mutants with similar nutritional requirements may represent two or more.closely linked genes (Mizobuchi et al. 1962). Numbers of colonies in control crosses between mutants and homologous donors were low (Table 2) which showed that the rever-

Table 3. Donor-phenotype transductions of cysG mutants with a cysC donor

\begin{tabular}{|c|c|c|c|c|}
\hline \multicolumn{3}{|c|}{ Cross } & \multirow{2}{*}{$\begin{array}{l}\text { Transductants } \\
\text { Prototrophs/total }\end{array}$} & \multirow{2}{*}{$\begin{array}{c}\text { Percentage } \\
\text { linkage }\end{array}$} \\
\hline Recipient & & Donor & & \\
\hline cys $G 9$ & $x$ & $\operatorname{cys} C \mathrm{~T}$ & $67 / 671$ & $90 \cdot 0 \mathrm{I}$ \\
\hline cysGII & $x$ & $\operatorname{cys} C I$ & $69 / 678$ & $98 \cdot 82$ \\
\hline cysGr5 & $x$ & cysCI & $82 / 788$ & 89.59 \\
\hline cysGr269 & $x$ & $\operatorname{cys} C r$ & $92 / 882$ & 89.57 \\
\hline cys $G 6$ & $x$ & cys $C I$ & $85 / 810$ & $89 \cdot 5 \mathrm{I}$ \\
\hline cysG 306 & $x$ & cysCI & $103 / 974$ & 89.43 \\
\hline cys $G_{5}$ & $x$ & $\operatorname{cys} C I$ & $75 / 704$ & $89 \cdot 35$ \\
\hline $\operatorname{cys}_{3}$ & $\times$ & $\operatorname{cys} C I$ & $84 / 780$ & $89 \cdot 23$ \\
\hline cysG8 & $x$ & $\operatorname{cys} C \mathrm{I}$ & $98 / 907$ & $89 \cdot 20$ \\
\hline cysGI262 & $x$ & $\operatorname{cys} C I$ & $91 / 837$ & $89 \cdot 13$ \\
\hline cys $G_{7}$ & $x$ & $\operatorname{cys} C I$ & $82 / 840$ & $88 \cdot 92$ \\
\hline cysGI4 & $x$ & $\operatorname{cys} C I$ & $105 / 940$ & 88.83 \\
\hline cysGI7 & $x$ & $\operatorname{cys} C I$ & $84 / 74 I$ & $88 \cdot 66$ \\
\hline cysG 373 & $x$ & $\operatorname{cys} C I$ & $87 / 750$ & $88 \cdot 40$ \\
\hline cysG20 & $x$ & cys $C I$ & $93 / 77 \mathrm{I}$ & $87 \cdot 94$ \\
\hline cys $G I$ & $x$ & cys $C I$ & $93 / 762$ & $87 \cdot 80$ \\
\hline cysG2 & $x$ & cys $C I$ & $81 / 635$ & $87 \cdot 24$ \\
\hline cys $_{4}$ & $x$ & $\operatorname{cys} C I$ & $106 / 809$ & 86.90 \\
\hline cysGIg & $x$ & $\operatorname{cys} C I$ & I I I / 8 I 5 & $86 \cdot 38$ \\
\hline cysGI795 & $x$ & cysCI & $96 / 666$ & $85 \cdot 59$ \\
\hline cysGI6 & $x$ & cys $C \mathrm{I}$ & $106 / 706$ & 84.99 \\
\hline
\end{tabular}

Table 4. Reciprocal donor-phenotype transductions between

\begin{tabular}{|c|c|c|}
\hline \multicolumn{3}{|c|}{ Cross } \\
\hline Recipient & & Donor \\
\hline cysE7 & $x$ & $\operatorname{argEI}$ \\
\hline $\arg E I$ & $x$ & cys $E_{7}$ \\
\hline cysE663 & $x$ & argEII \\
\hline $\arg E I$ & $x$ & cysE663 \\
\hline cysE699 & $x$ & $\arg E r$ \\
\hline $\arg E I$ & $x$ & cysE699 \\
\hline cysEg & $x$ & $\arg E I$ \\
\hline $\operatorname{argEI}$ & $x$ & cysEg \\
\hline cysE3o & $x$ & $\operatorname{argEI}$ \\
\hline $\operatorname{argEI}$ & $x$ & cys $E_{30}$ \\
\hline cysE6 & $x$ & $\operatorname{argEI}$ \\
\hline $\arg E I$ & $x$ & cysE6 \\
\hline cysE554 & $x$ & $\arg E I$ \\
\hline $\operatorname{argEI}$ & $x$ & cysE554 \\
\hline cysEIOOZ & $x$ & $\operatorname{argEI}$ \\
\hline $\arg E I$ & $x$ & cysEIo \\
\hline
\end{tabular}

cys $E$ mutants and $\arg E_{\mathrm{I}}$

\begin{tabular}{|c|c|c|}
\hline $\begin{array}{l}\text { Transductants } \\
\text { Prototrophs/total }\end{array}$ & $\begin{array}{l}\text { Percentage } \\
\text { linkage }\end{array}$ & Average \\
\hline $\begin{array}{l}520 / 682 \\
421 / 544\end{array}$ & $\left.\begin{array}{l}23 \cdot 75 \\
22 \cdot 61\end{array}\right\}$ & $23 \cdot 18$ \\
\hline $472 / 614$ & $23 \cdot 13\}$ & \\
\hline $533 / 694$ & $23.20\}$ & $23 \cdot 17$ \\
\hline $389 / 507$ & $23 \cdot 27\}$ & 0206 \\
\hline $463 / 597$ & $22.45\}$ & $22 \cdot 86$ \\
\hline $524 / 688$ & $23 \cdot 84\}$ & \\
\hline $539 / 688$ & $21 \cdot 66\}$ & $22 \cdot 75$ \\
\hline $463 / 600$ & $22 \cdot 83\}$ & \\
\hline $558 / 716$ & $22 \cdot 07\}$ & $22 \cdot 45$ \\
\hline $337 / 435$ & $22 \cdot 53\}$ & \\
\hline $385 / 492$ & $21 \cdot 75\}$ & $22 \cdot I 4$ \\
\hline $426 / 549$ & $22: 40\}$ & \\
\hline $48 \mathrm{I} / 6 \mathrm{IO}$ & $2 \mathrm{I} \cdot \mathrm{I} 5\}$ & $21 \cdot 78$ \\
\hline $521 / 671$ & $22 \cdot 35\}$ & \\
\hline $426 / 542$ & $21 \cdot 40\}$ & $21 \cdot 88$ \\
\hline
\end{tabular}


sion frequency of the mutants was low. Linkage between $c y s B$ and trp is probably not detectable in two-point crosses since the genes are located far apart. Co-transduction of $c y s C$ and $G, c y s E$ and $\arg E$, and $c y s B$ and $\operatorname{trp}$ was demonstrated in donor-phenotype transductions (Tables 3, 4 and 5, respectively) and by transduction of double mutants to prototrophy with wild-type donors. Reciprocal crosses between cys $C$ and $G$ (Table 3) were not possible since cys $G$ represents a block distal to $c y s C$ and the $c y s G$ phenotype cannot be selected in crosses with cys $G$ donors. The average percentage linkage values calculated from the donorphenotype transductions are $88.8 \%$ for $c y s C-G, 22.5 \%$ for $\operatorname{cys} E-\arg E$ and $\mathrm{I} \cdot 5 \%$ for cysB-trp.

\section{DISCUSSION}

The nutritional requirements of the six phenotypic groups of cysteine auxotrophs confirm findings (Grabow \& Smit, 1967) that the pathways of synthesis of this amino acid are similar in Proteus mirabilis, Salmonella typhimurium and Escherichia coli (Dreyfuss \& Monty, 1963; Jones-Mortimer, I968; Becker \& Tomkins, 1969). This pathway seems to operate also in Pseudomonas aeruginosa (Calhoun \& Feary, 1969). Growth responses to $O$-acetylserine indicate that $P$. mirabilis cys $K$ auxotrophs resemble cys $E$ mutants of $S$. typhimurium and $E$. coli which are deficient in the serine transacetylase activity of the cysteine synthetase enzyme (Jones-Mortimer, Wheldrake \& Pasternak, 1968). The $P$. mirabilis cys $E$ mutants seem to lack the $O$-acetylserine sulphydrylase activity of the latter enzyme, a phenotype which despite various efforts (Becker \& Tomkins, 1969; Kredich, Becker \& Tomkins, 1969) has not been detected amongst $S$. typhimurium or E. coli mutants. It thus appears that $P$. mirabilis cys $E$ auxotrophs are not the equivalent of $c y s E$ mutants of $S$. typhimurium as has previously been reported (Prozesky \& Coetzee, I966; Grabow \& Smit, 1967; Prozesky, 1968).

The scattered arrangement of cysteine genes and co-transduction of cysB and trp in Proteus mirabilis has also been reported in Salmonella typhimurium (Mizobuchi et al. 1962) and Escherichia coli (Jones-Mortimer, 1968). The $P$. mirabilis cys $G$ auxotrophs, which are closely linked to cys $C$, have nutritional requirements similar to cys $G, I$ or $J$ mutants of $S$. typhimurium and it seems that the cysC, D, H,I,J cluster of the latter organism is also present in $P$. mirabilis. It would appear that the topography of cysteine genes in $P$. mirabilis resembles that of analogous genes in S. typhimurium (Fig. 2) and E. coli. Experiments on the isolation of a marker which can be used to determine whether the orientation of the cysB-trp linkage group in $P$. mirabilis corresponds to that in $S$. typhimurium or $E$. coli are in progress. Similarities in topography between $P$. mirabilis and $S$. typhimurium or $E$. coli have also been found with arginine (Prozesky, 1968) and methionine genes (Grabow, 1972).

The distance between $c y s B$ and trp seems to be different in Proteus mirabilis and Sal-

Table 5. Reciprocal donor-phenotype transductions between

$\begin{array}{ccl}\text { Recipient } & & \text { Donor } \\ \text { cysBI4 } & \times & \operatorname{trp-I} \\ \operatorname{trp}-I & \times & \text { cysBI4 } \\ \text { cysB2o } & \times & \operatorname{trp}-I \\ \operatorname{trp}-I & \times & \text { cys } B 20 \\ \text { cysBI7 } & \times & \operatorname{trp}-I \\ \operatorname{trp}-I & \times & \text { cysBI7 }\end{array}$
cys $B$ mutants and trp-I

$\left.\begin{array}{cc}\begin{array}{c}\text { Transductants } \\ \text { Prototrophs/total }\end{array} & \begin{array}{c}\text { Percentage } \\ \text { linkage }\end{array} \\ \begin{array}{c}562 / 568 \\ 631 / 636\end{array} & \begin{array}{r}1 \cdot 1 \\ 625 / 636\end{array} \\ 734 / 744 & \mathrm{I} \cdot 7 \\ 538 / 548 & \mathrm{I} \cdot 3 \\ 593 / 605 & \mathrm{I} \cdot 8 \\ 2 \cdot 0\end{array}\right\}$

Average
$1 \cdot 0$
$1 \cdot 5$
$1 \cdot 9$




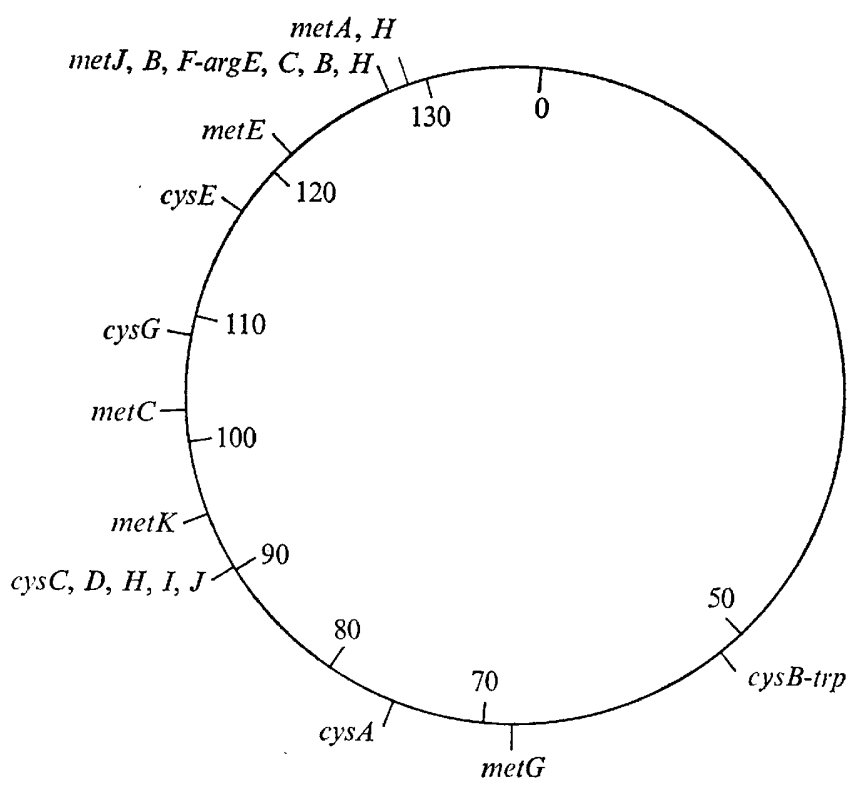

Fig. 2. Topography of cysteine genes in Salmonella typhimurium (Mizobuchi et al. 1962; Sanderson, 1970). Genes are shown on the outside of the circle. Arabic numbers on the inside indicate interrupted conjugation time intervals in min. Linked genes appear on the same line in clockwise order from left to right.

monella typhimurium since the percentage linkage between these markersis $\mathrm{I} \cdot 5 \%$ in the former (Table 5) and 56 to $82 \%$ in the latter (Demerec \& Hartman, 1956). The difference in these values reflects a difference in chromosomal distance since the transducing phages 13 and P22 have similar head sizes (Prozesky et al. 1965) and are thus expected to carry equivalent sections of host chromosome (Lennox, 1955; Enomoto, 1967; Sanderson, 1970; Mise \& Suzuki, 1970). Genetic differences between $P$. mirabilis and $S$. typhimurium are expected since they have different guanine+cytosine molar contents (see Grabow, 1972).

This work was partly supported by grants from the South African Medical Research Council to Professor J. N. Coetzee.

\section{REFERENCES}

Adams, M. H. (1959). Bacteriophages. New York: Interscience Publishers.

BeCKer, M. A. \& TOMkINs, G. M. (1969). Pleiotrophy in a cysteine-requiring mutant of Salmonella typhimurium resulting from altered protein-protein interaction. Journal of Biological Chemistry 244, 60236030.

BöHME, H. (1964). Über den Einfluss von Mutationen im Genom des Donor-Stammes auf dieTransduktionsfähigkeit des Proteus-Phagen $\pi 1$. In Struktur und Funktion des genetischen Materials, pp. 107-1 I I. Berlin: Akademie Verlag.

Calmoun, D. H. \& Feary, T. W. (1969). Transductional analysis of Pseudomonas aeruginosa methionineless auxotrophs. Journal of Bacteriology 97, 210-216.

Clowes, R. C. (1958a). Nutritional studies of cysteineless mutants of Salmonella typhimurium. Journal of General Microbiology 18, I40-153.

CLOWEs, R. C. (1958b). Investigation of the genetics of cysteineless mutants of Salmonella typhimurium by transduction. Journal of General Microbiology 18, 154-172. 
Coetzee, J. N. \& Prozesky, O. W. (1969). Arginine gene clusters of Proteus hauseri, P. morganii and Providence organisms. Proceedings of the South African Socicty of Pathologists, pp. 77-79.

CoEtzee, J. N."\& SACKs, T. G. (1960a). Intrastrain transduction in Proteus mirabilis. Nature, London 185, 869-870.

CoetzeE, J. N. \& SACKs, T. G. (1960 b). Transduction of streptomycin resistance in Proteus mirabilis. Journal of General Microbiology 23, 445-455.

Coetzee, J. N. \& Smit, J. A. (1970). Properties of Proteus mirabilis phage 13 vir. Journal of General Virology 9, 247-249.

Coetzee, J. N., Smit, J. A. \& Prozesky, O. W. (1966). Properties of Providence and Proteus morganii transducing phages. Journal of General Microbiology 44, I67-1 76.

Demerec, M. \& Hartman, Z. (1956). Tryptophan mutants in Salmonella typhimurium. In Genetic Studies with Bacteria, pp. 5-33. Washington: Publications of the Carnegie Institution 6I2.

Demerec, M., Moser, H., Clowes, R. C., Lahr, E. L., Ozeki, J. \& Vielmetter, W. (I956). In Bacterial Genetics, pp. 30I-315. Washington: Year Book of the Carnegie Institution 55.

Dreyfuss, J. \& MonTY, K. J. (1963). The biochemical characterization of cysteine-requiring mutants of Salmonella typhimurium. Journal of Biological Chemistry 238, Ior9-1024.

Dubnau, D., Goldthwaite, C., Smith, I. \& Marmur, J. (1967). Genetic mapping in Bacillus subtilis. Journal of Molecular Biology 27, 163-185.

ENomoto, M. (1967). Composition of chromosome fragments participating in phage P22-mediated transduction of Salmonella typhimurium. Virology 33, 474-482.

Flavin, M. \& Slaughter, C. (1965). Synthesis of the succinic ester of homoserine, a new intermediate in the bacterial biosynthesis of methionine. Biochemistry 4, 1370-1 375 .

Gillespie, D., Demerec, M. \& Itikawa, H. (I968). Appearance of double mutants in aged cultures of Salmonella typhimurium cysteine-requiring strains. Genetics 59, 433-442.

Grabow, W. O. K. (1972). Transductional analysis of methionine genes in Proteus mirabilis. Heredity (in the press).

Grabow, W. O. K. \& SMIT, J. A. (1967). Methionine synthesis in Proteus mirabilis. Journal of General Microbiology 46, 47-57.

Hartman, P. E., Loper, J. C. \& Šerman, D. (1960). Fine structure mapping by complete transduction between histidine-requiring Salmonella mutants. Journal of General Microbiology 22, 323-353.

Henderson, R. J., \& Loughin, R. E. (1968). Complementation in vitro between cysteine auxotrophs of Salmonella typhimurium. Biochimica et biophysica acta 156, 195-197.

Hopwood, D. A. (1967). Genetic analysis and genome structure in Streptomyces coelicolor. Bacteriological Reviews 31, 373-403.

Horowitz, N. H. (1947). Methionine synthesis in Neurospora. The isolation of cystathionine. Journal of Biological Chemistry 171, 255-264.

Itikawa, H. \& Demerec, M. (1967). Ditto deletions in the cysC region of the Salmonella chromosome. Genetics 55, 63-68.

JoNES, D. \& SNEATH, P. H. A. (1970). Genetic transfer and bacterial taxonomy. Bacteriological Reviews 34, $40-8 \mathrm{I}$.

JONES-MORTIMER, M. C. (1968). Positive control of sulphate reduction in Escherichiacoli. Isolation, characterization and mapping of cysteineless mutants of $E$. coli K12. Biochemical Journal 110, 589-595.

Jones-Mortimer, M. C., Wheldrake, J. F. \& PASTERnaK, C. A. (1968). The control of sulphate reduction in Escherichia coli by $O$-acetyl-L-serine. Biochemical Journal 107, $5 \mathrm{I}-53$.

Kredich, N. M., BeCKer, M. A. \& Tomkins, G. M. (1969). Purification and characterization of cysteine synthetase, a bifunctional protein complex, from Salmonella typhimurium. Journal of Biological Chemistry 244, 2428-2439.

KREDICH, N. M. \& TomkINs, G. M. (I966). The enzymatic synthesis of L-cysteine in Escherichia coli and Salmonella typhimurium. Journal of Biological Chemistry 24r, 4955-4965.

Krizsanovich, K., De KleRK, H. C. \& Smit, J. A. (1969). A transducing bacteriophage for Proteus rettgeri. Journal of General Virology 4, 437-439.

Lampen, J. O., Jones, M. J. \& Perkins, A. B. (1947). Studies on the sulfur metabolism of Escherichia coli. I. The growth characteristics and metabolism of a mutant strain requiring methionine. Archives of Biochemistry 13, 33-45.

LEDERBERG, J. \& LEDERBERG, E. M. (1952). Replica plating and indirect selection of bacterial mutants. Journal of Bacteriology 63, 399-406. 
Leinweber, F. J. \& Monty, K. J. (I96I). The mode of utilization of cysteine sulfinic acid by bacteria. Biochemical and Biophysical Research Communications 6, 355-358.

LENNox, E. S. (1955). Transduction of linked genetic characters of the host by bacteriophage Pr. Virology $\mathbf{r}$, 190-206.

MIsE, K. \& SUZUKI, K. (1970). New generalized transducing bacteriophage in Escherichia coli. Journal of Virology 6, 253-255.

Mizobuchi, K., Demerec, M. \& Gillespie, D. H. (1962). Cysteine mutants of Salmonella typhimurium. Genetics 47, $1617-1627$.

Postgate, J. R. (1963). The examination of sulphur auxotrophs: a warning. Journal of General Microbiology 3o, $48 \mathrm{I}-484$.

PROZESKY, O. W. (1967). Arginine synthesis in Proteus mirabilis. Journal of General Microbiology 49, 325-334.

Prozesky, O. W. (1968). Transductional analysis of arginineless mutants in Proteus mirabilis. Journal of General Microbiology 54, I27-143.

Prozesky, O. W. \& CoetzeE, J. N. (I966). Linked transduction in Proteus mirabilis. Nature, London 209, I 262.

Prozesky, O. W., De Klerk, H. C. \& Coetzee, J. N. (1965). The morphology of Proteus bacteriophages. Journal of General Microbiology 41, 29-36.

SANDERSON, K. E. (1970). Current linkage map of Salmonella typhimurium. Bacteriological Reviews 34, 176I93.

SiegeL, L. M., Click, E. M. \& MoNTY, K. J. (1964). Evidence for a two-step electron flow from TPNH to sulfite and hydroxylamine in extracts of Salmonella typhimurium. Biochemical and Biophysical Research Communications 17, 125-129.

Simmonds, S. (1948). Utilization of sulfur-containing amino acids by mutant strains of Escherichia coli. Journal of Biological Chemistry 174, 717-722.

Spencer, H. T., Collins, J. \& MonTy, K. J. (1967). Sequential regulation of cysteine biosynthesis in Salmonella typhimurium. Federation Proceedings of the Federation of American Societies for Experimental Biology 27, 677.

TAYLOR, A. L. (1970). Current linkage map of Escherichia coli. Bacteriological Reviews 34, I55-175. 